\title{
RISK FACTORS FOR CARBAPENEM-RESISTANT KLEBSIELLA PNEUMONIAE HOSPITAL INFECTION IN THE INTENSIVE CARE UNIT
}

Zorana M. Djordjevic ${ }^{1}$, Marko M. Folic ${ }^{2,3}$, Nevena Gajovic ${ }^{3}$ and Slobodan M. Jankovic ${ }^{2,3}$

${ }^{1}$ Department to Control Hospital Infections, Clinical Centre Kragujevac, Kragujevac, Serbia ${ }^{2}$ Clinical Pharmacology Department, Clinical Centre Kragujevac, Kragujevac, Serbia ${ }^{3}$ Faculty of Medical Sciences, University of Kragujevac, Kragujevac, Serbia

\author{
FAKTORI RIZIKA ZA NASTANAK BOLNIČKIH INFEICIJA \\ UZROKOVANIH KLEBSIELLA PNEUMONIAE REZISTENTNOM \\ NA KARBAPENEME U JEDINICAMA INTENZIVNE NEGE

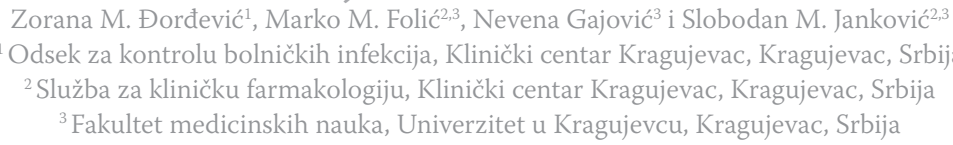

Received / Primljen: 18. 07. 2016.

Accepted / Prihvaćen: 25. 02. 2017.

\begin{abstract}
Carbapenem-resistant Klebsiella pneumoniae (CR-Kp) has become a major threat to patients in hospitals, increasing mortality, length of stay and costs.

The aim of this study was to discover risk factors for the development of hospital infections (HIs) caused by CR-Kp.

A prospective cohort study was conducted in the Medical-Surgical Intensive Care Unit of the Clinical Centre in Kragujevac, Kragujevac, Serbia, from January 1, 2011, to December 31, 2015. The "cases" were patients with HIs caused by CR-Kp, while the "controls" were patients infected with carbapenem-sensitive Klebsiella pneumoniae $(C S-K p)$. The significance of multiple putative risk factors for HIs caused by CR-Kp was tested using multivariate logistic regression.

Although univariate analyses pointed to many risk factors, with a significant influence on the occurrence of hospital CR-Kp infections, the multivariate logistic regression identified five independent risk factors: use of mechanical ventilation ( $O R=6.090 ; 95 \% \quad C I=1.030-36.020 ; \quad p=0.046)$; length of antibiotic therapy before HIs (days) (OR=1.080; 95\% CI=1.003-1.387; $p=0.045)$; previous use of carbapenems (OR=7.005; 95\% CI=1.054-46.572; $p=0.044)$; previous use of ciprofloxacin (OR=20.628; 95\% CI=2.292-185.687; $p=0.007)$ and previous use of metronidazole $(O R=40.320$; 95\% $C I=2.347-692.795 ; p=0.011$ )

HIs caused by CR-Kp are strongly associated with the use of mechanical ventilation and the duration of the previous use of certain antibiotics (carbapenems, ciprofloxacin and metronidazole).
\end{abstract}

Key Words: Klebsiella pneumoniae; Antimicrobial drug resistance; Hospital infections; Risk factors

\section{SAŽETAK}

Klebsiella pneumoniae rezistentna na karbapeneme (CR-Kp) postala je velika opasnost za hospitalizovane pacijente, obzirom da povećava smrtnost, produžava boravak u bolnici i dovodi do većih troškova lečenja.

Utvrditi potencijalne faktore rizika za razvoj bolničkih infekcija uzrokovanih sa CR-Kp.

Sprovedena je prospektivna kohortna studija u Intenzivnoj nezi Kliničkog centra Kragujevac (Kragujevac, Republika Srbija) u periodu od 1. januara 2011. godine do 31. decembra 2015. godine. "Slučajevi" su bili pacijenti sa bolničkim infekcijama uzrokovanim CR-Kp, dok su "Kontrole" cinili pacijenti inficirani Klebsiella pneumoniae (CS-Kp) patogenom osetlivim na karbapeneme. Značaj potencijalnih faktora rizika za razvoj bolničke infekcije uzrokovane sa CR-Kp ispitan je logističkom regresijom.

Mada je univarijantna analiza ukazala na značajan uticaj brojnih faktora rizika na razvoj intrahospitalnih infekcija uzrokvanih sa CR-Kp, multivarijantnom analizom je, pak, identifikovano pet nezavisnih faktora rizika za razvoj infekcije sa CR-Kp: upotreba mehaničke ventilacije $(O R=6.090$; 95\% CI=1.030-36.020; $p=0.046$ ), dužina primene antibiotske terapije pre nastanka bolničke infekcije (OR=1.080; 95\% $C I=1.003-1.387 ; p=0.045)$, prethodna upotreba karbapenema (OR=7.005; 95\% CI=1.054-46.572; $p=0.044)$, prethodna upotreba ciprofloksacina (OR=20.628; 95\% CI $=2.292$ 185.687; $p=0.007)$ i prethodna upotreba metronidazola $(\mathrm{OR}=40.320$; 95\% $C I=2.347-692.795 ; p=0.011)$

Bolničke infekcije izazvane sa CR-Kp udružene su sa primenom mehaničke ventilacije kao $i$ dužinom prethodne primene odredenih antibiotika (karbapenemi, ciprofloksacin $i$ metronidazol).

Ključne reči: Klebsiella pneumoniae; rezistencija na antibiotike, bolnicke infekcije; faktori rizika

\section{sciendo}

UDK: 616.98:579.842 / Ser J Exp Clin Res 2018; 19 (3): 255-261 DOI: 10.2478/SJECR-2018-0002 


\section{INTRODUCTION}

In recent years, due to uncritical use of carbapenems in the Intensive Care Unit (ICU), there are numerous reports of a progressive increase in the incidence of severe and lifethreatening hospital infections (HIs) by gram-negative bacteria that are resistant to these antibiotics. An important example of such a microorganism is the carbapenem-resistant Klebsiella pneumoniae (CR-Kp), which has become a major threat to hospitals, increasing mortality, length of stay, and cost (1-4). An additional difficulty is the multi-resistant nature of such isolates, which further complicates the treatment of HIs due to limited choices for effective antibiotics.

Recent studies shed light on some risk factors for CR-Kp acquisition (5-8). However, the importance of the prior use of antibiotics has been little investigated. Modern medicine requires additional knowledge for prevention of these infections and for the optimal choice of empirical antibiotic therapy.

The aim of our study was to discover the risk factors for the development of HIs caused by CR-Kp. These may be crucial for implementing efficient infection control measures to decrease the spread of these pathogens. In addition, this study analysed the sensitivity of isolates to the most frequently used antibiotics.

\section{MATERIALS AND METHODS}

\section{Hospital settings and the study population}

This study was conducted in the 18-bed Medical-Surgical ICU of the Clinical Centre Kragujevac, Kragujevac, Serbia, during the 5-year period from January 1, 2011, to December 31,2015 . The inclusion criteria for the study participants were (a) a stay in the ICU > 48 hours, (b) development of HIs caused by Klebsiella pneumoniae with any localization and (c) age $>18$ years. The exclusion criteria were (a) isolation of pathogens within 48 hours of admission and (b) repeated sampling from the same location of infection.

\section{Study design and definition of the study groups}

A prospective cohort study design was used that involved construction of two study groups. The "cases" were patients with HIs caused by CR-Kp, while the "controls" were patients infected with carbapenem-sensitive Klebsiella pneumoniae (CS-Kp).

\section{Microbiology and susceptibility testing}

The isolates were identified to the species level using conventional biochemical methods in the Microbiology Laboratory of Clinical Centre Kragujevac (9). Antimicrobial susceptibilities were determined by the disk diffusion method or with a Vitek-2 automated system (BioMerieux, France) for the following antibiotics: amoxicillin+clavulanic acid $(30 \mu \mathrm{g} / \mathrm{mL})$, piperacillin- tazobactam $(110 \mu \mathrm{g} / \mathrm{mL})$, ce- fotaxime $(30 \mu \mathrm{g} / \mathrm{mL})$, ceftriaxone $(30 \mu \mathrm{g} / \mathrm{mL})$, ceftazidime $(30 \mu \mathrm{g} / \mathrm{mL})$, cefepime $(30 \mu \mathrm{g} / \mathrm{mL})$, imipenem $(10 \mu \mathrm{g} / \mathrm{mL})$, meropenem $(10 \mu \mathrm{g} / \mathrm{mL})$, gentamicin $(10 \mu \mathrm{g} / \mathrm{mL})$, amikacin $(30 \mu \mathrm{g} / \mathrm{mL})$, ciprofloxacin $(5 \mu \mathrm{g} / \mathrm{mL})$, trimethoprimsulfamethoxazole $(2.5 \mu \mathrm{g} / \mathrm{mL})$ and tigecycline $(15 \mu \mathrm{g} / \mathrm{mL})$. All isolates with intermediate sensitivity or resistance to the tested antibiotic were considered resistant. The results were interpreted according to the guidelines issued by The Clinical and Laboratory Standards Institute (CLSI) (10).

CR-Kp was determined if Klebsiella pneumoniae isolates were resistant to both tested carbapenems (imipenem and meropenem). In cases of discrepancy, imipenem resistance served as the reference. According to the latest recommendations, multi-resistance was defined as acquired non-susceptibility to at least one agent from three or more different antibiotic groups, and pan-resistance as non-susceptibility to all antimicrobial categories (11).

\section{Definition HIs and data collection}

Diagnosis and anatomical localization of HIs caused by Klebsiella pneumoniae were determined by the Centers for Disease Control (CDC) criteria (12). Surveillance of HIs included daily clinical examination of patients and daily review of the patients' medical records. To exclude the patients colonized with Klebsiella pneumoniae, each of the cases was analysed by an independent expert group composed of an infectologist, epidemiologist, specialist of intensive medicine and clinical pharmacologist. The patients were followed to the final outcome, either cure and discharge from the hospital or death.

Patient data and potential risk factors were extracted from the medical records and the recording order on the standardized questionnaire for each patient, which had two sets of data:

a. related to patient characteristics: demographics (age and gender) and co-morbid conditions (hypertension, diabetes mellitus, cancer of different localization, injury), and

b. related to health care: urgent admission, dates of admission and discharge (to the hospital and to the ICU), diagnostic and therapeutic procedures performed (venous catheters, mechanical ventilation, surgery within a month), date of the first isolation of positive Klebsiella pneumoniae culture, and data about administered antibiotics. Prior exposure to antibiotics was defined as administration of a systemic antimicrobial agent for at least 24 hours during the 14-day period before isolation of Klebsiella pneumoniae.

The Ethics Committee of the health institution approved the study.

\section{Statistical analysis}

The data obtained were processed using descriptive statistics with measures of central tendency (mean), variability (standard deviation from the mean) and relative numbers. The significance of differences in the values of the continuous variables between the study groups was 
Table 1. Hospital infection sites caused by carbapenem-resistant Klebsiella pneumoniae (CR-Kp) and carbapenem-sensitive Klebsiella pneumoniae (CS-Kp) in Intensive Care Unit

\begin{tabular}{|c|c|c|c|c|}
\hline Anatomical site & $\begin{array}{c}\text { CR-Kp } \\
\text { n (\%) }\end{array}$ & $\begin{array}{c}\text { CS-Kp } \\
\text { n (\%) }\end{array}$ & $\begin{array}{l}\text { Total } \\
\text { n (\%) }\end{array}$ & p value \\
\hline Surgical site infection & $7(10.3)$ & $3(8.1)$ & $10(9.6)$ & 0.715 \\
\hline Nosocomial pneumonia & $53(77.9)$ & $31(83.8)$ & $84(80.0)$ & 0.475 \\
\hline Blood stream infection & $8(11.8)$ & $3(8.1)$ & $11(10.4)$ & 0.559 \\
\hline Total & $68(100.0)$ & $37(100.0)$ & $105(100.0)$ & \\
\hline
\end{tabular}

tested by Student's T-test for independent samples. The chi-square test or Fisher's test (for values in cells of contingency tables lower than 5 or zero) were used for comparison of categorical variables between the groups. Independent variables detected as significant predictors in univariate analysis were later entered into the multivariate logistic regression model. The hypotheses were tested at the 0.05 level of statistical significance. All calculations were performed using SPSS (Statistical Package for Social Science for Windows) software, version 18.

\section{RESULTS}

During the study period in the ICU, there were 105 patients who developed HIs caused by Klebsiella pneumoniae, according to the pre-defined criteria. Three-quarters were male $(n=78 ; 74.3 \%)$ and the average age of the patients was $59.37 \pm 15.37$ years (range $20-85$ years). In 68 patients $(64.8 \%)$, the HIs were caused by CR-Kp, while 37 (35.2\%) of the HIs were caused by CR-Kp. The predominant anatomical location of infection in both groups was

Table 2. Risk factors for hospital infections caused by carbapenem-resistant Klebsiella pneumoniae (CR-Kp) (univariate analysis)

\begin{tabular}{|c|c|c|c|}
\hline Variable & $\begin{array}{c}\text { CR-Kp } \\
n=68(\%)\end{array}$ & $\begin{array}{c}\text { CS-Kp } \\
\mathbf{n}=37(\%)\end{array}$ & p value \\
\hline Age & $61.01 \pm 14.68$ & $56.35 \pm 16.54$ & 0.140 \\
\hline Male gender & $50(73.5)$ & $28(75.7)$ & 0.810 \\
\hline \multicolumn{4}{|l|}{ Comorbidities } \\
\hline Hypertension & $13(19.1)$ & $4(10.8)$ & 0.270 \\
\hline Diabetes mellitus & $6(8.8)$ & $1(2.7)$ & 0.230 \\
\hline Cancer & $18(26.5)$ & $3(8.1)$ & $0.025 \%$ \\
\hline Injury & $21(30.9)$ & $16(43.2)$ & 0.205 \\
\hline Concomitant HIs & $33(48.5)$ & $9(24.3)$ & $0.016^{*}$ \\
\hline \multicolumn{4}{|l|}{ Invasive procedures } \\
\hline Central venous catheter & $57(83.8)$ & $18(48.6)$ & $<0.001^{*}$ \\
\hline Periferal venous catheter & $63(92.6)$ & $35(94.6)$ & 0.702 \\
\hline Mechanical ventilation & $58(85.3)$ & $24(64.9)$ & $0.016 \%$ \\
\hline Surgical intervention & $57(83.8)$ & $24(64.9)$ & $0.027^{*}$ \\
\hline \multicolumn{4}{|l|}{ Hospitalization } \\
\hline Emergency admission & $62(91.2)$ & $34(91.9)$ & 0.900 \\
\hline Hospital (days) & $37.68 \pm 19.84$ & $24.95 \pm 11.56$ & $0.001^{*}$ \\
\hline Hospital $>1$ month & $43(63.2)$ & $11(29.7)$ & $0.001^{*}$ \\
\hline ICU (days) & $27.91 \pm 12.94$ & $15.78 \pm 8.54$ & $<0.001^{*}$ \\
\hline ICU > 1 month & $32(47.1)$ & $3(8.1)$ & $<0.001^{*}$ \\
\hline Lenght before HIs (days) & $18.21 \pm 12.54$ & $10.83 \pm 5.86$ & $0.001^{*}$ \\
\hline \multicolumn{4}{|l|}{ Previous antibiotics use } \\
\hline Days of antibiotic therapy before HIs & $14.15 \pm 7.17$ & $7.86 \pm 14.91$ & $<0.001^{*}$ \\
\hline Piperacillin-tazobactam & $4(5.9)$ & $0(0)$ & 0.133 \\
\hline Carbapenems & $28(41.2)$ & $3(8.1)$ & $<0.001 \%$ \\
\hline $2^{\text {nd }}$ gen. cephalosporin & $18(26.5)$ & $10(27.0)$ & 0.951 \\
\hline $3^{\text {rd }}$ gen. cephalosporin & $22(32.4)$ & $12(32.4)$ & 0.993 \\
\hline Aminoglycosides & $30(44.1)$ & $8(21.6)$ & $0.022 \%$ \\
\hline Ciprofloxacin & $18(26.5)$ & $2(5.4)$ & $0.009^{*}$ \\
\hline Vancomycin & $18(26.5)$ & $1(2.7)$ & $0.003^{*}$ \\
\hline Metronidazol & $20(29.4)$ & $1(2.7)$ & $0.001^{*}$ \\
\hline
\end{tabular}

Results are presented as $\bar{x}_{ \pm \mathrm{SD}}$, or n (\%);

* significant difference

CR-Kp - carbapenem-resistant Klebsiella pneumoniae

CS-Kp - carbapenem- sensitive Klebsiella pneumoniae

ICU - Intensive Care Unit 
Table 3. Multivariate analysis (logistic regression) of risk factors for hospital infection caused by carbapenem-resistant Klebsiella pneumoniae

\begin{tabular}{|c|c|c|c|c|}
\hline Risk factors & B & p value & OR & $95 \% \mathrm{CI}$ \\
\hline Mechanical ventilation & 1.807 & 0.046 & 6.090 & $1.030-36.020$ \\
\hline Days of antibiotic therapy before HIs & 0.165 & 0.045 & 1.080 & $1.003-1.387$ \\
\hline Previous Carbapenems use & 1.947 & 0.044 & 7.005 & $1.054-46.572$ \\
\hline Previous Ciprofloxacin use & 1.121 & 0.007 & 20.628 & $2.292-185.687$ \\
\hline Previous Metronidazol use & 3.697 & 0.011 & 40.320 & $2.347-692.795$ \\
\hline
\end{tabular}

Only significant factors are presented for the sake of clarity.

$B$ - coefficient of logistic regression analysis;

OR- Odds Ratio

CI - Confidence Interval

pneumonia $(80.0 \%)$, followed by bloodstream infections and surgical-site infections (10.4\% vs. $9.6 \%$, respectively). The difference between study groups relative to the site of HIs was not statistically significant ( $>0.05$ ) (Table 1$)$.

Table 2 shows the results of the univariate analysis of potential risk factors for HIs caused by CR-Kp relative to clinical characteristics, invasive procedures and prior therapy. According to this analysis, risk factors significantly associated with the development of these infections were co-morbidities such as cancer or concomitant HIs, the use of invasive medical procedures such as placement of central venous catheter or mechanical ventilation or surgical intervention, a prolonged stay in hospital/ICU, the use of antibiotics before emergence of infection, and previous administration of carbapenems, aminoglycosides, ciprofloxacin, vancomycin or metronidazole $(\mathrm{p}<0.05)$.

Multivariate logistic regression identified five independent risk factors for CR-Kp infections: the use of mechanical ventilation $(O R=6.090 ; 95 \% C I=1.030-36.020 ; p=0.046)$, length of antibiotic therapy before HIs (days) $(\mathrm{OR}=1.080$; 95\% $\mathrm{CI}=1.003-1.387 ; \mathrm{p}=0.045)$, and previous use of carbapenems $(\mathrm{OR}=7.005$; 95\% $\mathrm{CI}=1.054-46.572$; $\mathrm{p}=0.044)$, cip- rofloxacin $(\mathrm{OR}=20.628 ; 95 \% \mathrm{CI}=2.292-185.687 ; \mathrm{p}=0.007)$ and metronidazole $(\mathrm{OR}=40.320 ; 95 \% \mathrm{CI}=2.347-692.795$; $\mathrm{p}=0.011$ ) (Table 3). The Hosmer-Lemeshow Goodnessof-Fit Test for this logistic regression model was $\chi^{2}=5.223$; $\mathrm{p}=0.734$.

Resistance rates (\%) of the tested isolates of Klebsiella pneumoniae to other antibiotics are shown in Table 4. For the majority of antibiotics, it was over $85 \%$, except for piperacillintazobactam (59.8\%) and tigecycline (14.0\%). However, isolates of CR-Kp had a significantly higher incidence of resistance to the following antibiotics than the CS-Kp isolates: piperacillintazobactam ( $80.4 \%$ vs. $25.8 \%$ respectively; $\mathrm{p}<0.001)$, amikacin (93.7\% vs. $71.4 \%$ respectively; $\mathrm{p}=0.003)$, ciprofloxacin $(98.4 \%$ vs. $80.0 \%$ respectively; $\mathrm{p}=0.001$ ) and trimethoprim-sulfamethoxazole ( $95.0 \%$ vs. $76.2 \%$ respectively; $\mathrm{p}=0.029$ ). Nearly two-thirds of the isolates were multi-resistant $(n=67 ; 63.8 \%)$, while 7 (6.7\%) were pan-resistant.

Lethal outcomes occurred in the $36(52.9 \%)$ patients with CR-Kp and 14 (37.8\%) with CS-Kp infections, but the difference was not statistically significant $(\mathrm{p}=0.139)$.

In this period, the outbreaks of HIs caused by Klebsiella pneumoniae were not recorded.

Table 4. Comparison of antimicrobial resistance of Klebsiella pneumoniae to selected antibiotics

\begin{tabular}{|c|c|c|c|}
\hline Antimicrobial agent & $\begin{array}{c}\text { CR-Kp } \\
\text { n/N (\%) }\end{array}$ & $\begin{array}{c}\text { CS-Kp } \\
\mathbf{n} / \mathbf{N}(\%)\end{array}$ & p value \\
\hline Amoxicillin+clavulanic acid & $43 / 44(97.7)$ & $31 / 32(96.9)$ & 0.819 \\
\hline Piperacillin-tazobactam & $41 / 51(80.4)$ & $8 / 31(25.8)$ & $<0.001^{*}$ \\
\hline Cefotaxime & $44 / 44(100.0)$ & $27 / 28(96.4)$ & 0.207 \\
\hline Ceftriaxone & $52 / 52(100.0)$ & $34 / 34(100.0)$ & - \\
\hline Ceftazidime & $61 / 61(100.0)$ & $33 / 33(100.0)$ & - \\
\hline Cefepime & $57 / 64(89.1)$ & $28 / 34(82.4)$ & 0.351 \\
\hline Gentamicin & $35 / 35(100.0)$ & $23 / 23(100.0)$ & - \\
\hline Amikacin & $59 / 63(93.7)$ & 25/35 (71.4) & $0.003^{*}$ \\
\hline Ciprofloxacin & $62 / 63(98.4)$ & $28 / 35(80.0)$ & $0.001^{*}$ \\
\hline Trimethoprim-sulfamethoxazole & $38 / 40(95.0)$ & $16 / 21(76.2)$ & $0.029^{*}$ \\
\hline Tigecyclin & $6 / 42(14.3)$ & $2 / 15(13.3)$ & 0.927 \\
\hline
\end{tabular}

$\mathrm{n}=$ number of resistant isolates and $\mathrm{N}=$ number of isolates with available results

* significant difference

CR-Kp - carbapenem-resistant Klebsiella pneumoniae

CS-Kp - carbapenem- sensitive Klebsiella pneumoniae 


\section{DISCUSSION}

Klebsiella pneumoniae has become an important challenge in health-care settings due to its frequency in HIs and the incidence of resistance to the entire spectrum of antibiotics (13). We still do not know what predisposes patients to acquire infections with resistant strains of Klebsiella pneumoniae. Therefore, we conducted a prospective cohort study to analyse the association between numerous potential risk factors and HIs caused by CR-Kp among patients in the ICU. Most previous studies were retrospective, which imposed a bias in the interpretation of the results (differentiation between infection and colonization), and data derived from mixed medical and critical care populations are biased because the prevalence of patients was small. Our study showed that the CR-Kp is essentially a "healthcare-associated infection". Multivariate analysis pointed to five significant risk factors, none of which were patient-related.

When overviewing the role of invasive medical procedures in the development HIs caused by CR-Kp, only mechanical ventilation emerged as an independent risk factor, which was expected because previous studies also pointed to this factor (14). According to our results, mechanical ventilation increased the risk of these infections 6.1-fold (95\% CI=1.030-36.020; $\mathrm{p}=0.046$ ). Patients in the ICU often require mechanical ventilation due to respiratory failure, poor gas exchange, and lung and neurologic injury, but this procedure also opens the pathway for the entrance of infectious agents. Microorganisms from the environment adhere to respiratory support equipment and form a biofilm, which is out of reach of antibiotics and neutrophils. Patients with unrecognized CR-Kp colonization are especially important since they are reservoirs for the further transmission of these bacteria $(15,16)$. To reduce these infections, it is prudent to use non-invasive ventilation instead, such as nasal continuous positive pressure ventilation or nasal synchronized intermittent mandatory ventilation.

Previous exposure to antibiotics is often associated with the occurrence of HIs caused by resistant pathogens. For this research, it was defined as at least 24 hours of therapy with antibiotics within 14 days before the isolation of Klebsiella pneumoniae. Multivariate analysis showed that the duration of the previous use of antibiotics was associated with a risk of CR-Kp infection. Longer exposure to antimicrobial therapy can be considered an additional factor in the destruction of protective barriers because it promotes colonization and infection by drug-resistant pathogens. The selection of these strains contributes to the broad-spectrum antibiotics widely used in many ICUs. In patients with prolonged antimicrobial therapy, normal microbiological flora are replaced with endemic bacterial strains from the hospital environment, which are often multi-resistant.

In our study, previous exposure to carbapenems predisposed patients for HIs caused by CR-Kp by 7.0-fold (95\%
$\mathrm{CI}=1.054-46.572 ; \mathrm{p}=0.044)$ consistent with the results of previous studies $(17,18)$. According to the case-control study by Wu and associates (14), an independent risk factor for contracting CP-Kp infection is the previous use of carbapenems $(\mathrm{OR}=12.69,95 \% \mathrm{CI}=2.09-77.10 ; \mathrm{p}=0.006)$. These beta-lactam antibiotics with broad-spectrum activity destroy the susceptible bacterial strains that colonized patients and facilitate the selection of multi-resistant pathogens.

Introduction of a new generation of fluoroquinolones with improved activity against respiratory pathogens and improved pharmacokinetics led to the wide use of these antibiotics for empirical therapy in critically ill patients. However, we must better understand their role in the development of bacterial resistance. Our study showed that the risk of HIs caused by CR-Kp after the use of ciprofloxacin was 20.6-fold higher (95\% CI=2.292-185.687; $\mathrm{p}=0.007$ ). Schwaber and associates (19) found that the prior use of fluoroquinolones was related to CR-Kp isolation, and only the strength of association was low $(\mathrm{OR}=7.2,95 \% \mathrm{CI}=1.1-$ 49.4; $\mathrm{p}=0.04)$. This should be considered when evaluating the potential benefits and harms of administering ciprofloxacin to patients in the ICU.

The previous use of metronidazole is also associated with HIs caused by CR-Kp, which is of broad relevance since it is frequently used in patients residing in the ICU. Metronidazole decreases the burden of anaerobic bacteria and creates room for invasion by multi-resistant hospital flora, including Klebsiella pneumoniae.

Broad-spectrum antibiotics select multi-resistant bacterial strains because they eradicate concurrent, yet sensitive, microorganisms. However, in our study, previous use of piperacillin-tazobactam, second- and thirdgeneration cephalosporins, aminoglycosides or vancomycin were not associated with HIs caused by CR-Kp, after adjustment for other variables (aminoglycosides and vancomycin showed significant influences when taken separately, at $\mathrm{p}=0.022$ and $\mathrm{p}=0.003$, respectively). The finding is unexpected, considering the generally accepted link between antimicrobial use and resistant bacteria. This should probably be attributed to the recent administration of a variety of agents to the majority of patients included in the study. Some recent studies have presented results similar to ours (5). All of this suggests that the correlation between antimicrobial use and resistance is a much more complex phenomenon.

Klebsiella pneumoniae became resistant to almost all available antimicrobial agents (20). This is alarming because a high resistance rate for most tested antibiotics was recorded (over 85\%), while only tigecycline sensitivity was still preserved (rate of resistance is 14.0\%). In addition, two-thirds of isolates were multi-resistant (63.8\%). In a recent study similar to ours (21), the rates of antibiotic resistance were lower, as were the percentages of multiand pan-resistant isolates (47.1\% and $1.2 \%)$. Treatment of patients with these infections is prolonged, expensive and bears increased mortality (22). 
An especially worrying result of this study is the high rate of carbapenem-resistant isolates $(n=78 ; 74.3 \%)$. These antibiotics are often used as a drug of last resort in combating gram-negative infections that are resistant to other antibiotics. The most important mechanism of resistance of carbapenems is the production of a carbapenemase enzyme, blaKPC. The gene for this enzyme is carried on a mobile piece of genetic material, which increases the risk for dissemination, even to other Enterobacteriaceae $(23,24)$. The emergence and spread of CR-Kp underlines the need for immediate aggressive detection and control strategies to preserve their efficacy in the future (25).

In conclusion, HIs caused by CR-Kp are strongly associated with the use of mechanical ventilation and the duration of the previous use of certain antibiotics (carbapenems, ciprofloxacin and metronidazole). These results should help doctors to identify at-risk patients to implement measures to prevent the onset of CR-Kp infections. The results can also contribute to crafting appropriate institutional policy for antibiotics utilization and the development of effective strategies for the prevention of these infections.

\section{ACKNOWLEDGEMENTS}

This study was partially financed by Research grant No. 175007 from the Serbian Ministry of Education, Science and Technological Development.

The authors have no conflicts of interest concerning its content or conclusions.

\section{REFERENCES}

1. Patel G, Huprikar S, Factor SH, Jenkins SG, Calfee DP. Outcomes of carbapenem-resistant Klebsiella pneumoniae infection and the impact of antimicrobial and adjunctive therapies. Infect Control Hosp Epidemiol. 2008;29:1099-106.

2. Munoz-Price LS, Quinn JP. The spread of Klebsiella pneumonia carbapenemases: a tale of strains, plasmids, and transposons. Clin Infect Dis. 2009;49:1739-41.

3. Chitnis AS, Caruthers PS, Rao AK, Lamb J, Lurvey R, Beau De Rochars V et al. Outbreak of carbapenemresistant Enterobacteriaceae at a long-term acute care hospital: sustained reductions in transmission through active surveillance and targeted interventions. Infect Control Hosp Epidemiol. 2012;33:984-92.

4. Falagas ME, Tansarli GS, Karageorgopoulos DE, Vardakas KZ. Deaths Attributable to Carbapenem- Resistant Enterobacteriaceae Infections. Emerging Infectious Diseases. 2014; 20: 1170-5.

5. Kofteridis DP, Valachis A, Dimopoulou D, Maraki S, Christidou A, Mantadakis E et al. Risk factors for carbapenem-resistant Klebsiella pneumoniae infec- tion/colonization: a case-case-control study. J Infect Chemother. 2014;20:293-7.

6. Hussein K, Raz-Pasteur A, Finkelstein R, Neuberger A, Shachor-Meyouhas Y, Oren I et al. Impact of carbapenem resistance on the outcome of patients' hospital-acquired bacteraemia caused by Klebsiella pneumoniae. J Hosp Infect. 2013;83:307-13.

7. Correa L, Martino MD, Siqueira I, Pasternak J, Gales AC, Silva CV et al. A hospital-based matched case-control study to identify clinical outcome and risk factors associated with carbapenem-resistant Klebsiella pneumoniae infection. BMC Infect Dis. 2013;13:80.

8. Ulu AC, Kurtaran B, Inal AS, Kömür S, Kibar F, Çiçekdemir HYet al. Risk Factors of Carbapenem-Resistant Klebsiella pneumoniae Infection: A Serious Threat in ICUs. Medical Science Monitor: International Medical Journal of Experimental and Clinical Research. 2015; 21: 219-24.

9. Kiska DL, Gilligan PH. Pseudomonas and Burkholderia. In: Murray PR, Baron EJ, Pfaller MA, et al. (editors). Manual of clinical microbiology. Washington [DC]: American Society for Microbiology; 1995. p. 517-25.

10. CLSI: Clinical and Laboratory Standard Institute (CLSI). Performance standards for antimicrobial susceptibility testing. Wayne, PA, USA. 2010.

11. Magiorakos AP, Srinivasan A, Carey RB, Carmeli Y, Falagas ME, Giske CG et al. Multidrug-resistant, extensively drug-resistant and pandrug-resistant bacteria: an international expert proposal for interim standard definitions for acquired resistance. Clin Microbiol Infect. 2012;18:268-81.

12. Garner JS, Jarvis WR, Emori TG, Horan TC, Hughes JM. CDC definitions for nosocomial infections. Am J Infect Control 1988;16:128-40.

13. Nordmann P, Cuzon G, Naas T. The real threat of Klebsiella pneumoniae carbapenemase-producing bacteria. Lancet Infect Dis. 2009;9(4):228-36.

14. $\overline{\mathrm{Wu}} \mathrm{D}$, Cai J, Liu J. Risk factors for the acquisition of nosocomial infection with carbapenem-resistant Klebsiella pneumoniae. South Med J. 2011;104:106-10.

15. Samra Z, Ofir O, Lishtzinsky Y, Madar-Shapiro L, Bishara J. Outbreak of carbapenem-resistant Klebsiella pneumoniae producing $\mathrm{KPC}-3$ in a tertiary medical centre in Israel. Int J Antimicrob Agents. 2007;30:525-9.

16. Borer A, Saidel-Odes L, Eskira S, Nativ R, Riesenberg K, Livshiz-Riven I et al. Risk factors for developing clinical infection with carbapenem-resistant Klebsiella pneumoniae in hospital patients initially only colonized with carbapenem-resistant K. pneumoniae. Am J Infect Control. 2012;40:421-25.

17. Orsi GB, García-Fernández A, Giordano A, Venditti C, Bencardino A, Gianfreda $\mathrm{R}$ et al. Risk factors and clinical significance of ertapenem-resistant Klebsiella pneumoniae in hospitalised patients. J Hosp Infect. 2011;78:54-8. 
18. Hu Y, Ping Y, Li L, Xu H, Yan X, Dai H. A retrospective study of risk factors for carbapenem-resistant Klebsiella pneumoniae acquisition among ICU patients . J Infect Dev Ctries. 2016;10:208-13.

19. Schwaber MJ, Klarfeld-Lidji S, Navon-Venezia S, Schwartz D, Leavitt A, Carmeli Y. Predictors of carbapenem-resistant Klebsiella pneumoniae acquisition among hospitalized adults and effect of acquisition on mortality. Antimicrob Agents Chemother. 2008;52:1028-33.

20. Nathisuwan S, Burgess DS, Lewis JS. Extended-Spectrum $\beta$-Lactamases: Epidemiology, Detection and Treatment. Pharmacother. 2001;(8):920-8.

21. Vardakas KZ, Matthaiou DK, Falagas ME, Antypa E, Koteli A, Antoniadou E. Characteristics, risk factors and outcomes of carbapenem-resistant Klebsiella pneumoniae infections in the intensive care unit. J Infect. 2015;70:592-9.
22. Young LS, Sabel AL, Price CS. Epidemiologic, clinical, and economic evaluation of an outbreak of clonal multidrug-resistant Acinetobacter baumannii infection in a surgical intensive care unit. Infect Control Hosp Epidemiol. 2007;28:1247-54.

23. Hudson C, Bent Z, Meagher R, Williams K. Resistance Determinants and Mobile Genetic Elements of an NDM-1-Encoding Klebsiella pneumoniae Strain. PLOS ONE . 2014;9:e99209.

24. Bratu S, Brooks S, Burney S, Kochar S, Gupta J, Landman D et al. Detection and spread of Escherichia coli possessing the plasmid-borne carbapenemase KPC-2 in Brooklyn, New York. Clin Infect Dis. 2007;44:972-5.

25. Spellberg B, Guidos R, Gilbert D, Bradley J, Boucher HW, Scheld WM et al. The epidemic of antibiotic-resistant infections: a call to action for the medical community from the Infectious Diseases Society of America. Clin Infect Dis. 2008;46:155-64. 